\title{
Mitochondrial peroxynitrite generation is mainly driven by superoxide steady-state concentration rather than by nitric oxide steady-state concentration
}

\begin{abstract}
In biological systems, $\mathrm{ONOO}^{-}$production depends on production rates of $\mathrm{NO}$ and $\mathrm{O}_{2}^{-}$, and on the reactions of these two free radicals with other biological components, which limit the local concentrations of $\mathrm{NO}$ and $\mathrm{O}_{2}^{-}$. In mitochondria, $\mathrm{O}_{2}^{-}$is generated through the auto oxidation of semiquinones at Complexes I and III, and it may suffer the SODcatalyzed dismutation reaction to produce $\mathrm{H}_{2} \mathrm{O}_{2}$ or react with $\mathrm{NO}$ in a classical termination reaction between free radicals. These diffusion-controlled reactions kinetically compete for $\mathrm{O}_{2}$ - degradation. Results from our laboratory have shown that even in physiopathological situations in which NO production is reduced, such as the mitochondrial dysfunction associated to stunned heart, mitochondrial $\mathrm{ONOO}^{-}$production rate may be slightly increased if the steady-state concentration of $\mathrm{O}_{2}^{-}$is augmented. The enhancement in $\mathrm{O}_{2}$ concentration leads to an increase in its degradation by reaction with $\mathrm{NO}$, decreasing $\mathrm{NO}$ bioavailability and increasing $\mathrm{ONOO}^{-}$production rate. Therefore, mitochondrial $\mathrm{ONOO}^{-}$ generation is mainly driven by $\mathrm{O}_{2}^{-}$rather than by $\mathrm{NO}$ steady-state concentrations. In this scenario, the switch from NO-signaling pathways to oxidative damage takes place. The modification of crucial biomolecules by nitration or oxidation can lead to the bioenergetics failure that underlies physiopathological conditions such as neurodegenerative diseases, ischemia-reperfusion, Diabetes, endotoxic shock and aging.
\end{abstract}

Volume 3 Issue 2 - 2018

Laura B Valdez, ${ }^{1,2}$ Silvina S Bombicino,' Darío E Iglesias, ${ }^{1,2}$ Ivana Rukavina Mikusic A, ${ }^{1,2}$ Alberto Boveris ${ }^{1,2}$

'University of Buenos Aires, Physical Chemistry Division, Argentina

${ }^{2}$ University of Buenos Aires, Institute of Biochemistry and Molecular Medicine (IBIMOL), Argentina

Correspondence: Laura B Valdez, Cátedra de Fisicoquímica, Facultad de Farmacia y Bioquímica, Universidad de Buenos Aires, Junín 956, CI I I 3AAD, Buenos Aires, Argentina, Tel+ 54-I I-52874235, Email lbvaldez@ffyb.uba.ar

Received: December 14, 2017 | Published: March 14, 2018

\section{Mitochondrialmatrix:ametabolically differentiated space}

The mitochondrial matrix is a metabolically differentiated intracellular space concerning superoxide $\left(\mathrm{O}_{2}^{-}\right)$, nitric oxide $(\mathrm{NO})$ and peroxynitrite $\left(\mathrm{ONOO}^{-}\right)$metabolism because of the impermeability of the mitochondrial inner membrane to $\mathrm{O}_{2}^{-}, \mathrm{H}^{+}$and $\mathrm{ONOO}^{-}$and the specific presence of relatively high concentrations of $\mathrm{Mn}$-superoxide dismutase (Mn-SOD), about 3-10 $\mu \mathrm{M}^{1}$ Superoxide anion $\left(\mathrm{O}_{2}^{-}\right)$is formed through the auto oxidation of ubisemiquinone ${ }^{2}$ at Complex III and of the flavin semiquinone of NADH dehydrogenises. ${ }^{3}$ In the mitochondrial matrix, $\mathrm{O}_{2}^{-}$is consumed through two diffusioncontrolled reactions (Figure 1): the disproportionate reaction catalyzed by $\mathrm{Mn}$-SOD $\left(\mathrm{k}=2.3 \times 10^{9} \mathrm{M}^{-1} \mathrm{~s}^{-1}\right)^{4,5}$ that produces $\mathrm{O}_{2}$ and hydrogen peroxide $\left(\mathrm{H}_{2} \mathrm{O}_{2}\right) ;{ }^{6-9}$ and the reaction with nitric oxide $(\mathrm{NO})$ to yield peroxynitrite $\left(\mathrm{ONOO} ; \mathrm{k}=1.9 \times 10^{10} \mathrm{M}^{-1} \mathrm{~s}^{-1}\right) .{ }^{10}$ Thus, from the kinetic point of view, these reactions compete for $\mathrm{O}_{2}{ }_{2}^{-}$degradation.

As a result of $\mathrm{O}_{2}^{-}$disproportionation, isolated respiring mitochondria produce $\mathrm{H}_{2} \mathrm{O}_{2}$ at rates that depend on the redox state of the components of the respiratory chain and, consequently, on the mitochondrial metabolic state. ${ }^{6,11}$ The rates of $\mathrm{H}_{2} \mathrm{O}_{2}$ production of mitochondria isolated from mammalian organs are in the range of 0.4-0.9 nmol $\mathrm{H}_{2} \mathrm{O}_{2} \times \min ^{-1} \times \mathrm{mg}$ protein ${ }^{-1}$ in state 4 and $0.05-0.15$

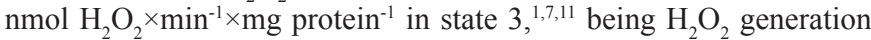
in state 4 about 4-16 times higher than in state 3., ${ }^{1,9}$ Hydrogen peroxide in the mitochondrial cristae space originates largely from mitochondrial Complex III, whereas mitochondrial Complex I contribute to mitochondrial matrix $\mathrm{H}_{2} \mathrm{O}_{2} \cdot{ }^{12}$ In the aristae subspace, "redox nanodomains" have been described which are induced by and control calcium signaling at the endoplasmic reticulum-mitochondrial interface. ${ }^{13}$ Hydrogen peroxide transients sensitize calcium ion release to maintain calcium oscillation. In this scenario, $\mathrm{H}_{2} \mathrm{O}_{2}$ is considered the major redox metabolite operative in redox sensing, signaling and redox regulation. ${ }^{14}$ While $1-10 \mathrm{nM} \mathrm{H}_{2} \mathrm{O}_{2}$ are considered physiological concentrations that play a role in redox signaling pathways under normal conditions, higher $\mathrm{H}_{2} \mathrm{O}_{2}$ concentrations lead to adaptive responses and supra physiological concentrations $(>100 \mathrm{nM})$ lead to damage of biomolecules. ${ }^{14}$

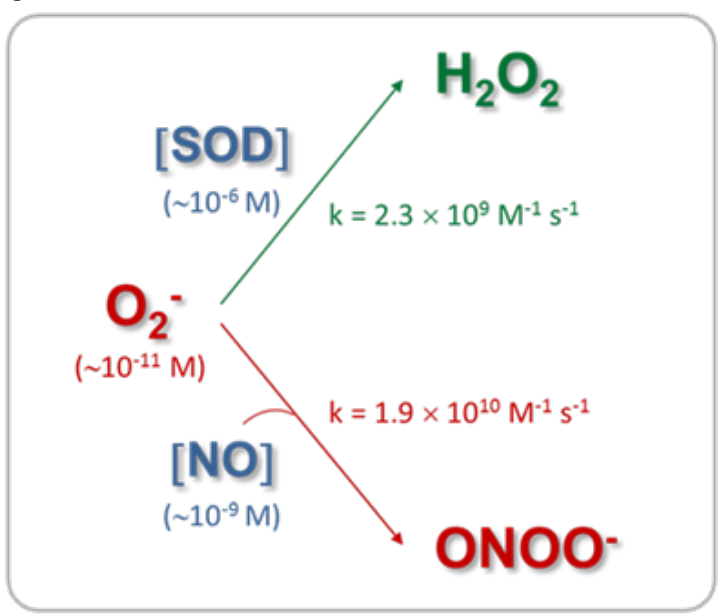

Figure I Mitochondrial $\mathrm{O}_{2}^{-}$is consumed by two competitive diffusioncontrolled reactions: the dismutation reaction catalyzed by SOD and the free radical termination reaction with $\mathrm{NO} . \mathrm{NO}$ and $\mathrm{O}_{2}^{-}$steady-state concentrations and SOD concentration in the mitochondrial matrix are shown between brackets. 
In addition, nitric oxide (NO) is produced through the reaction catalyzed by mitochondrial nitric oxide synthase (mtNOS), an isoenzyme of the NOS family located in the mitochondrial inner membrane that requires NADPH, L-arginine, $\mathrm{O}_{2}$ and $\mathrm{Ca}^{2+}$ for its enzymatic activity. ${ }^{15-20}$ Mitochondrial NOS is a highly regulated enzyme. ${ }^{21}$ Several reports have shown that mtNOS is regulated by the $\mathrm{O}_{2}$ partial pressure in the inspired air, ${ }^{22-25}$ the sympathetic autonomic system, ${ }^{26}$ the thyroid hormones,${ }^{27}$ insulin ${ }^{28}$ and angiotensin II. ${ }^{29}$ As well as $\mathrm{H}_{2} \mathrm{O}_{2}$ generation, mtNOS activity is modified by mitochondrial metabolic state: ${ }^{19,30,31}$ during the transition from resting to active respiration, NO release decreases about $40-45 \%$. Nitric oxide production depends on mitochondrial membrane potential $(\Delta \psi)$, being this dependence more important at physiological $\Delta \psi$ range $(150-180 \mathrm{mV}))^{30,31} \mathrm{In}$ addition, $\mathrm{mtNOS}$ expression and activity are positively regulated in inflammatory processes ${ }^{32,33}$ and positively or negatively modulated by pharmacological situations, ${ }^{34}$ such as haloperidol, ${ }^{35}$ chlorpromazine ${ }^{36}$ and enalapril treatments. ${ }^{37}$ Moreover, changes in mtNOS activity and expression have been associated to the role of $\mathrm{NO}$ as signaling molecule involved in mitochondrial biogenesis, ${ }^{38,39}$ understood as de novo formation of mitochondria during the cellular life cycle. In turn, the product of mtNOS activity, i.e. $\mathrm{NO}$, is an effective modulator of mitochondrial function ${ }^{40}$ through the inhibition that it exerts over Complex IV ${ }^{41-43}$ and Complex III ${ }^{44,45}$ activities. Mitochondrial NO is produced at rates of 1.0-1.5 nmol

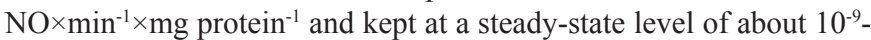
$10^{-8} \mathrm{M}$ in the mitochondrial matrix. ${ }^{30}$

When $\mathrm{O}_{2}^{-}$and $\mathrm{NO}$ are synthesized simultaneously and in close proximity, they will combine spontaneously to form $\mathrm{ONOO}^{-}$. This diffusion-limited reaction is a key element in deciding the roles of NO in physiology and pathology. ${ }^{46-48}$ Peroxynitrite is a strong oxidant ${ }^{49}$ that can directly react with biomolecules by one or two-electron oxidations. ${ }^{50}$ Peroxynitrite oxidizes the sulfhydryl group of cysteine and glutathione $(\mathrm{GSH}),{ }^{51}$ the sulfur atom of methionine, ${ }^{52}$ ascorbate, ${ }^{53}$ and the Purina and pyramiding bases of DNA. ${ }^{54}$ However, the reaction rate constants are relatively slow for these second-order reactions, ranging from $10^{3}$ to $10^{6} \mathrm{M}^{-1} \mathrm{~s}^{-1}$. ${ }^{44}$ Peroxynitrite is also able to start the lipoperoxidation process in biomembranes and liposome's ${ }^{55}$ and in isolated LDL. ${ }^{56}$ In addition, ONOO- can promote protein tyrosine and tryptophan nitration, and lipid nitration that serve as important biological markers in vivo. ${ }^{57,47}$ Tyrosine nitration affects protein structure and function, resulting in changes in the catalytic activity of enzymes, altered cytoskeletal organization, and impaired cell signal transduction and is thus increasingly considered as a central aspect of peroxynitrite-mediated cytotoxicity. ${ }^{58,59}$ Nevertheless, ONOO- is normally reduced by the mitochondrial reluctant NADH, ubiquinol $\left(\mathrm{UQH}_{2}\right)$ and GSH and kept at intramitochondrial steady-state level of about $5-10 \mathrm{nM}^{59}$ When the steady-state concentration of ONOO is enhanced at about $20-50 \mathrm{nM}$, tyrosine nitration, protein oxidation and damage to Fe-S centers might take place. Therefore, the switch from signaling pathways of NO to oxidative damage takes place. Peroxynitrite production rate enhancement has been found in a series of clinical conditions such as Parkinson's disease, ${ }^{60}$ ischemiareperfusion ${ }^{61}$ diabetes, ${ }^{62}$ endotoxicshock, ${ }^{32}$ and aging. ${ }^{63}$ In these physiopathological situations, partial inactivation and dysfunction of Complex I (NADH: ubiquinone oxidoreductase) was also observed. ${ }^{64}$ Because of the fact that mitochondrial Complex I is the major entry point for feeding the respiratory chain with the reducing equivalents and that it is one of the $\mathrm{H}^{+}$pumps that generates the mitochondrial
$\Delta \mu \mathrm{H}^{+}$needed for the subsequent ATP synthesis, changes in Complex I activity lead to impairment of mitochondrial capacity to produce ATP and to cellular bioenergetics imbalance which underlies the above cited pathologies. Moreover, the increase in $\mathrm{O}_{2}^{-}$production by modified Complex I intensify the enhancement in $\mathrm{ONOO}^{-}$generation, leading to a positive feedback toward oxidative damage. Figure 2 outlines the metabolism of reactive oxygen and nitrogen species, in the mitochondrial matrix.

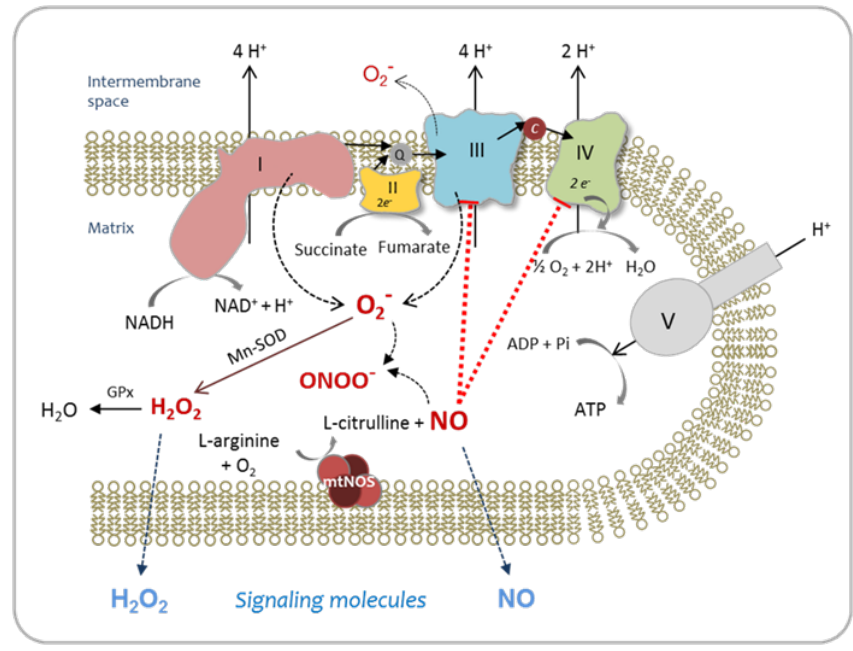

Figure 2 Metabolism of reactive oxygen and nitrogen species in mitochondrial matrix. The NO produced by mtNOS can readily interact with Complexes III and IV. $\mathrm{O}_{2}^{-}$is formed at Complexes I and III and undergoes a very fast reaction with $\mathrm{NO}$ to form ONOO- or it is catabolized by $\mathrm{Mn}-\mathrm{SOD}$ to form $\mathrm{H}_{2} \mathrm{O}_{2}$. $\mathrm{NO}$ and $\mathrm{H}_{2} \mathrm{O}_{2}$ are considered mitochondrion-cytosol signaling molecules.

\section{Kinetic control of ONOO-production in mitochondria}

Mitochondrial $\mathrm{ONOO}^{-}$generation depends on $\mathrm{NO}$ and $\mathrm{O}_{2}$ production rates and on the reactions of these two free radicals with other biological components, which limit the local concentrations of $\mathrm{NO}$ and $\mathrm{O}_{2}^{-}$. Results from our laboratory have shown that even in physiopathological situations in which $\mathrm{NO}$ production is reduced, mitochondrial $\mathrm{ONOO}^{-}$production rate may be slightly increased if the steady-state concentration of $\mathrm{O}_{2}^{-}$is augmented, with the consequent oxidation of biomolecules or modification of proteins by nitration. ${ }^{61,65}$ We have observed that in myocardial stunning ${ }^{61,65}$ and in streptozotocin (STZ)-induced diabetes, ${ }^{62,39}$ the cardiac mitochondrial dysfunction implied the reduction in state $3 \mathrm{O}_{2}$ consumption sustained by glutamate-malate, the decrease in mitochondrial Complex I-III activity, and the enhancement in $\mathrm{H}_{2} \mathrm{O}_{2}$ production rate (Table 1), among others. However, while in the mitochondrial dysfunction produced as a consequence of hyperglycemia, an increase in NO production rate $(23 \%)$ and in mtNOS expression $(132 \%)^{39}$ were observed together with a reduction $(50 \%)$ in Mn-SOD activity, in the mitochondrial impairment that accompanied the initial phase of stunned heart (15 min of ischemia and $30 \mathrm{~min}$ of reperfusion), a reduction in NO production rate $(28 \%)$, without changes in mtNOS expression and SOD activity ${ }^{61}$ were detected, as expected for an acute stress model. Strikingly, an increase in tyrosine nitration (about $60-80 \%$ ) of heart mitochondrial proteins was observed in both experimental models (Table 1). 
Table I Reactive species production rates and steady-state concentrations in heart mitochondria in physiopathological situations

\begin{tabular}{|c|c|c|c|c|}
\hline & \multicolumn{2}{|c|}{ Myocardial stunning\# } & \multicolumn{2}{|c|}{ STZ-induced diabetes\#\# } \\
\hline & Control $(0 / 0)$ & I/R (I5/30) & Control & Diabetes \\
\hline $\begin{array}{l}\mathrm{H}_{2} \mathrm{O}_{2} \text { production } \\
\left(\mathrm{nmol} \times \mathrm{min}^{-1} \times \mathrm{mg} \text { protein }{ }^{-1}\right)\end{array}$ & $0.18 \pm 0.02$ & $0.32 \pm 0.04 *$ & $0.40 \pm 0.19$ & $0.91 \pm 0.08 * * * *$ \\
\hline $\begin{array}{l}\text { Mn-SOD activity } \\
\left(U \times m g \text { protein }{ }^{-1}\right)\end{array}$ & $53 \pm 5$ & $56 \pm 3$ & $143 \pm 22$ & $7 I \pm 8^{*}$ \\
\hline $\begin{array}{l}\text { Active }[\mathrm{Mn}-\mathrm{SOD}] \# \# \\
(\mu \mathrm{M} \text { enzyme })\end{array}$ & $7.4 \pm 0.7$ & $7.9 \pm 0.4$ & $17 \pm 3$ & $8.5 \pm 0.9$ \\
\hline $\begin{array}{l}\text { NO production } \\
\left(\mathrm{nmol} \times \mathrm{min}^{-1} \times \mathrm{mg} \text { protein }{ }^{-1}\right)\end{array}$ & $0.90 \pm 0.05$ & $0.65 \pm 0.05^{* *}$ & $0.93 \pm 0.07$ & $1.14 \pm 0.06 *$ \\
\hline$[\mathrm{NO}]_{\mathrm{ss}}\left(10^{-9} \mathrm{M}\right)$ & 9.1 & 6.6 & 9.4 & 12 \\
\hline$[\mathrm{O} 2]_{\mathrm{ss}}\left(10^{-11} \mathrm{M}\right)$ & 4.8 & 8.1 & 4.7 & 21 \\
\hline ONOO-production $\left(\mathrm{nM} \times \mathrm{s}^{-1}\right)$ & 8.4 & 10.1 & 8.4 & 46 \\
\hline Tyr nitration (\%) & 100 & $178 *$ & 100 & $158 * * *$ \\
\hline
\end{tabular}

\#Experimental model of myocardial stunning: isolated rabbit hearts were exposed to ischemia (I; 15 min) and reperfusion (R; 30 min).

\#\#Exerimental model of type I Diabetes: rats were sacrificed after 28 days of Streptozotocin injection (STZ, 60 mg $\times \mathrm{kg}^{-1}$, ip.) and heart mitochondrial function was studied.

The concentration of Mn-SOD ( $\mu$ M enzyme) in the mitochondrial matrix was calculated as ( $\mu M$ active center)/4, because mammalian Mn-SOD is a homotetramer with a manganese ion per subunit. The concentration of Mn-SOD active centers was calculated taking into account the value of Mn-SOD activity, the amount of commercial SOD that inhibits $50 \%$ ferricytochrome c reduction by each SOD unit (I U SOD corresponds to 4 pmol SOD), the sample protein concentration $(0.3-1.0 \mathrm{mg}$ mitochondrial protein $\mathrm{ml}-\mathrm{I})$, and a volume of $7.2 \mu \mathrm{l}$ mitochondrial matrix $\times \mathrm{mg} \mathrm{protein}^{-1}$.

$*_{p}<0.05, * * p<0.01, * * * p<0.001$, **** $p<0.005$ significantly different respect to control (Myocardial stunning: one-way analysis of variance followed by Bonferroni multiple comparisons test; Diabetes, Student's t-test).

Taking into account the experimental values of $\mathrm{H}_{2} \mathrm{O}_{2}$ and $\mathrm{NO}$ production rates in both physiopathological situations and the $\mathrm{Mn}$ SOD concentration in the mitochondrial matrix calculated from MnSOD activity, the steady-state concentrations of $\mathrm{O}_{2}^{-}$and $\mathrm{NO}$ and the $\mathrm{ONOO}^{-}$production rate were estimated (Table 1) .

Superoxide anion production rate was calculated from the experimental $\mathrm{H}_{2} \mathrm{O}_{2}$ production values and considering the 2:1 stoichiometry of the disproportionation reaction of $\mathrm{O}_{2}^{-}$to $\mathrm{H}_{2} \mathrm{O}_{2}$,

$$
-d\left[\mathrm{O}_{2}^{-}\right] / d \mathrm{t}=2 d\left[\mathrm{H}_{2} \mathrm{O}_{2}\right] / d \mathrm{t}
$$

In the steady-state, the production rate is equal to the consumption rate of a chemical species. In the case of $\mathrm{O}_{2}^{-}$,

$$
-d\left[\mathrm{O}_{2}^{-}\right] / d \mathrm{t}=d\left[\mathrm{O}_{2}^{-}\right] / d \mathrm{t}
$$

Superoxide is consumed by the reaction with NO (reaction I) and the disproportionation reaction (reaction II) catalyzed by SOD:

$$
\begin{gathered}
\mathrm{O}_{2}^{-}+\mathrm{NO} \stackrel{\mathrm{k}_{1}}{\longrightarrow} \mathrm{ONOO}^{-} \\
2 \mathrm{O}_{2}^{-}+2 \mathrm{H}^{+} \stackrel{\mathrm{k}_{2}}{\longrightarrow} \mathrm{H}_{2} \mathrm{O}_{2}+\mathrm{O}_{2}
\end{gathered}
$$

Mitochondrial NO is produced by $\mathrm{mtNOS}$ and released into the mitochondrial matrix where $\mathrm{NO}$ reacts with $\mathrm{O}_{2}^{-}$(reaction I), ubiquinol $\left(\mathrm{UQH}_{2}\right)\left(\right.$ reaction III) and cytochrome oxidase $\left(\mathrm{cyt}^{\mathrm{a}} \mathrm{a}_{3-} \mathrm{e}^{3+}\right)$ (reaction IV):

$$
\begin{aligned}
& \mathrm{O}_{2}{ }^{-}+\mathrm{NO} \stackrel{\mathrm{k}_{1}}{\longrightarrow} \mathrm{ONOO}^{-} \\
& \mathrm{NO}+\mathrm{UQH}_{2} \stackrel{\mathrm{k}_{3}}{\longrightarrow} \mathrm{UQH}^{\cdot}+\mathrm{H}^{+}+\mathrm{NO} \\
& \mathrm{NO}+\mathrm{cytaa}_{3}-\mathrm{Fe}^{2+} \stackrel{\mathrm{k}_{4}}{\longrightarrow} \mathrm{cytaa}_{3}-\mathrm{Fe}^{3+}+\mathrm{NO}
\end{aligned}
$$

Thus, NO production rate was expressed as:

$d[\mathrm{NO}] / d \mathrm{t}=-d[\mathrm{NO}] / d \mathrm{t}=\mathrm{k}_{1}[\mathrm{NO}]\left[\mathrm{O}_{2}^{-}\right]+\mathrm{k}_{3}[\mathrm{NO}]\left[\mathrm{UQH}_{2}\right]+\mathrm{k}_{4}[\mathrm{NO}][\mathrm{cyt}$ $\left.\mathrm{aa}_{3}-\mathrm{Fe}^{2+}\right]$

Superoxide and NO steady-state concentrations $\left(\left[\mathrm{O}_{2}^{-}\right]_{\mathrm{ss}}\right.$ and $[\mathrm{NO}]_{\mathrm{ss}}$ ) were calculated from the equations 1 and 2 , respectively, by mathematical iteration, and using the following rate constants: $\mathrm{k}_{1}=1.9 \times 10^{10} \quad \mathrm{M}^{-1} \mathrm{~s}^{-1},{ }^{10} \quad \mathrm{k}_{2}=2.3 \times 10^{9} \quad \mathrm{M}^{-1} \quad \mathrm{~s}^{-1.4}, \mathrm{k}_{3}=1.5 \times 10^{4} \quad \mathrm{M}^{-1} \quad \mathrm{~s}^{-1,67}$ $\mathrm{k}_{4}=4.0 \times 10^{7} \mathrm{M}^{-1} \mathrm{~s}^{-1}{ }^{68}$

$$
\begin{aligned}
& {\left[\mathrm{O}_{2}^{-}\right]_{\mathrm{ss}}=2 d\left[\mathrm{H}_{2} \mathrm{O}_{2}\right] / d \mathrm{t} /\left(\mathrm{k}_{1}[\mathrm{NO}]+\mathrm{k}_{2}[\mathrm{Mn}-\mathrm{SOD}]\right)} \\
& {[\mathrm{NO}]_{\mathrm{ss}}=d[\mathrm{NO}] / d \mathrm{t} /\left(\mathrm{k}_{1}\left[\mathrm{O}_{2}^{-}\right]+\mathrm{k}_{3}\left[\mathrm{UQH}_{2}\right]+\mathrm{k}_{4}\left[\mathrm{cyt} \mathrm{aa}_{3}-\mathrm{Fe}^{2+}\right]\right)}
\end{aligned}
$$

Nitric oxide diffusion to and from cytosol was not included in Eq. 2. Ubiquinol and cytochrome aa $a_{3}$ contents were taken as $277 \mu \mathrm{M}$ and $5.6 \mu \mathrm{M}$, respectively, considering a mitochondrial matrix volume of $7.0 \mu 1 \times \mathrm{mg} \mathrm{protein}^{-1} .{ }^{66,69}$

Once the $\mathrm{O}_{2}^{-}$and $\mathrm{NO}$ steady-state concentrations were calculated, the $\mathrm{ONOO}^{-}$production rate was estimated from Eq. 3, taking into account the second-order rate constant $\mathrm{k}_{1}$ :

$$
d\left[\mathrm{ONOO}^{-}\right] / d \mathrm{t}=\mathrm{k}_{1}\left[\mathrm{O}_{2}^{-}\right][\mathrm{NO}]
$$

In the physiological conditions assessed (Table 1, control data), the mitochondrial $\mathrm{O}_{2}^{-}$steady-state concentrations calculated were about of $0.05 \mathrm{nM}$, because of its short half-life $(50-100 \mu \mathrm{s})$ and its degradation by the reaction catalyzed by Mn-SOD. In these experimental situations, $\mathrm{NO}$ steady-state concentrations have resulted $\sim 9 \mathrm{nM}$, more than 100-fold higher than $\mathrm{O}_{2}^{-}$concentration. Therefore, the second-order reaction rate between $\mathrm{O}_{2}^{-}$and $\mathrm{NO}$ to produce $\mathrm{ONOO}^{-}$is converted in a pseudo-first order reaction respect to $\mathrm{O}_{2}^{-}$, being $\mathrm{O}_{2}^{-}$concentration the driving factor to generate $\mathrm{ONOO}^{-}$in a given time. Consequently, under normal mitochondrial conditions, 
$\mathrm{ONOO}^{-}$production and concentration are relatively low. Moreover, taking into account that the rate constant of the $\mathrm{ONOO}^{-}$formation reaction is approximately 8 times higher than the rate constant of the $\mathrm{O}_{2}$ - dismutation reaction, physiological concentrations of SOD (in $\mu \mathrm{M}$ range) can effectively compete with $\mathrm{NO}$ concentration $(\mathrm{nM})$ for $\mathrm{O}_{2}$ consumption (Figure 1). It is known that in physiological situations, only about $15-20 \%$ of the $\mathrm{O}_{2}{ }^{-}$generated in mitochondria is catabolized through its reaction with NO; but this pathway consumes about $80 \%$ of mitochondrial NO. On the other hand, Table I shows that although the mitochondrial NO steady-state concentration is reduced $(28 \%)$ in the stunned heart, the $\mathrm{ONOO}^{-}$generation is slightly increased $(20 \%)$, mainly because of an increase $(70 \%)$ in $\mathrm{O}_{2}^{-}$steady-state concentration, leading to an increase $(\sim 80 \%)$ in nitration of tyrosine residues of mitochondrial proteins. Therefore, mitochondrial $\mathrm{ONOO}$ generation is mainly driven by $\mathrm{O}_{2}^{-}$steady-state concentration rather than by $\mathrm{NO}$ steady-state concentration. In pathological situations in which the $\mathrm{O}_{2}^{-}$steady-state concentration is increased and Mn-SOD expression is not modified, as it is the case in the stunned heart, the metabolic pathway of $\mathrm{O}_{2}^{-}$degradation through its reaction with $\mathrm{NO}$ is exacerbated, leading to an enhancement in $\mathrm{ONOO}^{-}$generation (Figure $3)$. In addition, in experimental diabetes, an increase in the NO steady-state $(28 \%)$ was observed together with a large increment in $\mathrm{O}_{2}$ - steady-state concentration ( 3.5 fold), this latter as a consequent of not only the enhancement of $\mathrm{O}_{2}^{-}$production but also the reduction in
SOD active concentration. This physiopathological situation caused a 5 -fold increase in $\mathrm{ONOO}^{-}$production rate in heart mitochondria from diabetic in comparison with control animals. Accordingly, when $\mathrm{O}_{2}$ - formation is stimulated more than two-fold the rate of $\mathrm{NO}$ synthesis and $\mathrm{Mn}-\mathrm{SOD}$ concentration is reduced, NO is quantitatively converted to $\mathrm{ONOO}^{-}$acquiring fundamental importance the $\mathrm{ONOO}^{-}$ derived chemical reactions (Figure 3 ). The conversion from reversible inhibition of cellular respiration by NO to pathological inhibition of mitochondrial function by the NO-derived $\mathrm{ONOO}^{-}$has been observed in many physiopathological conditions, and it seems to be controlled by $\mathrm{O}_{2}^{-}$steady-state concentration rather than by $\mathrm{NO}$ concentration. Mitochondrial dysfunction accompanied by $\mathrm{ONOO}^{-}$generation increase is a hallmark of heart hypoxia-reperfusion injury ${ }^{60}$ sepsis, ${ }^{32}$ diabetes, ${ }^{61}$ among others. Moreover, these results agree with the modulation of the NO bioavailability in the vascular endothelium, another interesting microenvironment. In this case, an increased $\mathrm{O}_{2}$ - production by NADPH oxidase (NOX 1 and NOS 2 isoforms) compromises the NO bioavailability, this latter fact associated. ${ }^{70}$ In a high-blood pressure experimental model, it has been observed that the flavanol(-)-epicatechin regulates NO bioavailability not only through the modulation of NOS activity but also by regulating $\mathrm{O}_{2}^{-}$production and NOX expression, suggesting that the reaction between $\mathrm{O}_{2}^{-}$and NO is a key pathway in the endothelium-dependent vasorelaxation process. $^{70}$

\section{Myocardial stunning}

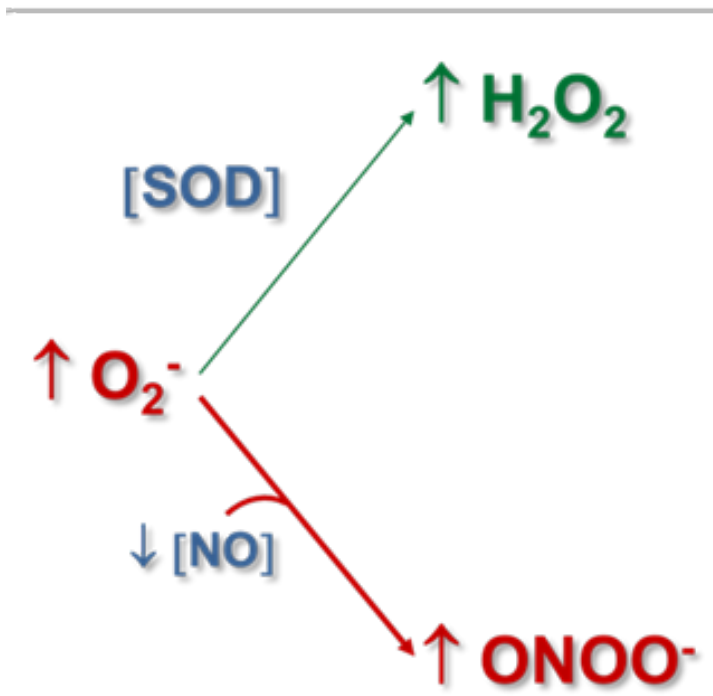

\section{STZ-induced Diabetes}

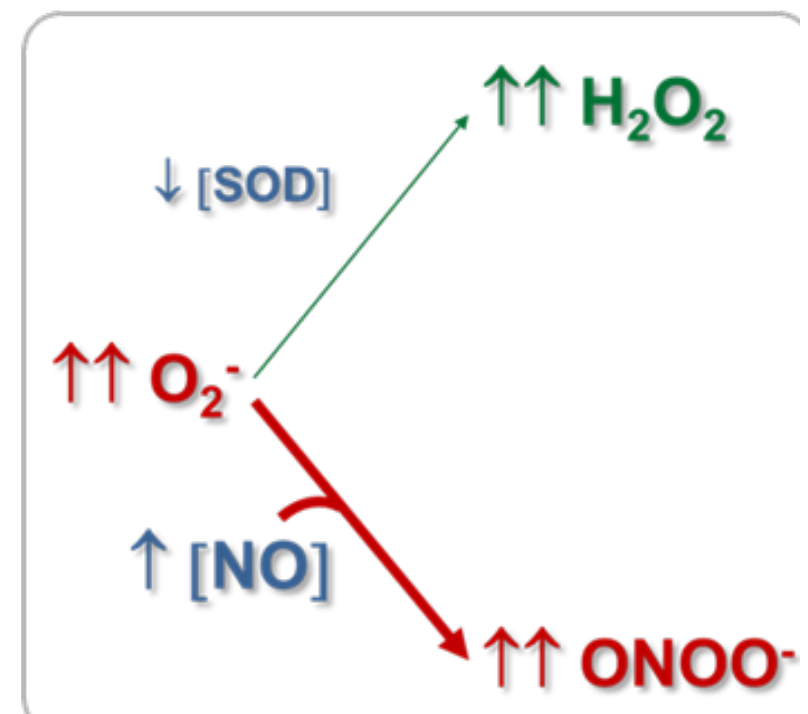

Figure 3 schematic representations showing the changes in the steady-state concentrations of reactive oxygen and nitrogen species, in two physio pathological situations in which heart mitochondrial dysfunction has been observed. Mitochondrial NO production decreased in the myocardial stunning while NO generation increased in STZ-induced diabetes. However, mitochondrial ONOO- production was increased in both physio pathological situations due to the enhancement in the $\mathrm{O}_{2}^{-}$steady-state concentration.

\section{Conclusion}

To conclude, in physiopathological conditions, $\mathrm{ONOO}^{-}$generation is mainly driven by $\mathrm{O}_{2}^{-}$steady-state concentration. The enhancement in $\mathrm{O}_{2}^{-}$concentration increases its degradation by reaction with $\mathrm{NO}$, declining $\mathrm{NO}$ bioavailability and increasing $\mathrm{ONOO}^{-}$concentration. This way, the switch from NO-signaling pathways to oxidative damage takes place, with protein tyrosine nitration, protein oxidation and damage to Fe-S centers. Among them, changes in Complex I structure and function can exacerbate $\mathrm{ONOO}^{-}$generation-secondary to $\mathrm{O}_{2}$ - production rate enhancement-producing to a positive feedback toward oxidative distress, bioenergetics failure and the subsequent cell death.

\section{Acknowledgements}

This work was supported by research grants from the University 
of Buenos Aires (UBACYT 200-201-301-00731 and 200-201-60100132), Agencies National de Promotion Scientific y Technological (ANPCYT, PICT 2014-0964), and Conseco National de Investigations Scientifics y Technical (CONICET; PIP 112-201-101-00444).

\section{Conflict of interest}

The author declare no conflict of interest.

\section{References}

1. Boveris A, Cadenas E. Cellular sources and steady-state levels of reactive oxygen species. In: Clerch LB, Massaro DJ, editors. Oxygen, gene expression and cellular function. New York: Marcel Deckker: Springer; 1997: p. 1-25.

2. Boveris A, Cadenas E. Mitochondrial production of superoxide anions and its relationship to the antimycin insensitive respiration. FEBS Lett. 1975;54(3):311-314.

3. Turrens JF, Boveris A. Generation of superoxide anion by the NADH dehydrogenase of bovine heart mitochondria. Biochem $J$ 1980;191(2):421-427.

4. Mc Cord JM, Fridovich I. Superoxide dismutase. An enzymic function for erythrocuprein (hemocuprein) $J$ Biol Chem. 1969;244(22):6049-6055.

5. Klug D, Rabani J, Fridovich I. A direct demonstration of the catalytic action of superoxide dismutase through the use of pulse radiolysis. $J$ Biol Chem. 1972;247:4839-4842.

6. Boveris A, Chance B. The mitochondrial generation of hydrogen peroxide. Biochem J. 1973;134(3):707-716.

7. Boveris A, Cadenas E, Stoppani AOM. Role of ubiquinone in the mitochondrial generation of hydrogen peroxide. Biochem $J$ 1976;156(2):435-444.

8. Cadenas E, Boveris A, Ragan CI, et al. Production of superoxide radicals and hydrogen peroxide by NADH-ubiquinone reductase and ubiquinol-cytochrome c reductase from beef-heart mitochondria. Arch Biochem Biophys. 1977;180(2):248-257.

9. Chance B, Sies H, Boveris A. Hydroperoxide metabolism in mammalian organs. Physiol Rev. 1979;59(3):527-605.

10. Kissner R, Nauser T, Bugnon P, et al. Formation and properties of peroxynitrite as studied by laser flash photolysis, high-pressure stopped-flow technique and pulse radiolysis. Chem Res Toxicol. 1997;10(11):1285-1292.

11. Boveris A, Valdez LB, Zaobornyj T, et al. Mitochondrial metabolic states regulate nitric oxide and hydrogen peroxide diffusion to the cytosol. Biochim Biophys Acta. 2006;1757(5-6):535-542

12. Bleier L, Wittig I, Heide H, et al. Generator-specific targets of mitochondrial reactive oxygen species. Free Radic Biol Med. $2015 ; 78: 1-10$

13. Booth DM, Enyedi B, Geiszt M, et al. Redox nanodomains are induced by and control Calcium signaling at the ER-mitochondrial interface. Mol Cell. 2016;63(2):240-248.

14. Sies H. Hydrogen peroxide as a central redox signaling molecule in physiological oxidative stress: Oxidative eustress. Redox Biol. 2017:11:613-619.

15. Ghafourifar P, Richter C. Nitric oxide synthase activity in mitochondria. FEBS Lett. 1997;418(3):291-296.

16. Giulivi C, Poderoso JJ, Boveris A. Production of nitric oxide by mitochondria. J Biol Chem. 1998;273:11038-11043.

17. Tatoyan A, Giulivi C. Purification and characterization of a nitric-oxide synthase from rat liver mitochondria. $J$ Biol Chem.
1998;273(18):11044-11048.

18. Elfering SL, Sarkela TM, Giulivi C. Biochemistry of mitochondrial nitric-oxide synthase. J Biol Chem. 2002;277(41):38079-38086.

19. Traaseth N, Elfering S, Solien J, et al. Role of calcium signaling in the activation of mitochondrial nitric oxide synthase and citric acid cycle. Biochim Biophys Acta. 2004;1658(1-2):64-71.

20. Ghafourifar P, Cadenas E. Mitochondrial nitric oxide synthase Trends Pharmacol Sci. 2005;26(4):190-195.

21. Valdez LB, Zaobornyj T, Bombicino S, et al. Physiological regulation of heart mitochondrial nitric oxide synthase. In: Alvarez S, Evelson P, editors. Free Radical Pathophysiology. India: Transword Research Network; 2008: p. 177-190.

22. Alvarez S, Valdez LB, Zaobornyj T, et al. Oxygen dependence of mitochondrial nitric oxide synthase activity. Biochem Biophys Res Commun. 2003;305(3):771-775.

23. Valdez LB, Zaobornyj T, Alvarez S, et al. Heart mitochondrial nitric oxide synthase. Effects of hypoxia and aging. Mol Aspects Med. 2004:25(1-2):49-59.

24. Gonzales GF, Chung A, Miranda S, et al. Heart mitochondrial nitric oxide synthase is upregulated in male rats exposed to high altitude (4,340 m). Am J Physiol Heart Circ Physiol. 2005;288(6):2568-2573.

25. Zaobornyj T, Valdez LB, La Padula P, et al. Effect of sustained hypobaric hypoxia during maturation and aging on rat myocardium. II. mtNOS activity. $J$ Appl Physiol. 2005;98(6):2370-2375.

26. Fellet AL, Balaszczuk AM, Arranz C, et al. Autonomic regulation of pacemaker activity: role of heart nitric oxide synthases. Am J Physiol Heart Circ Physiol. 2006;291(3):1246-1254.

27. Carreras MC, Peralta JG, Converso DP, et al. Modulation of liver mitochondrial NOS is implicated in thyroid-dependent regulation of $\mathrm{O}_{2}$ uptake. Am J Physiol Heart Circ Physiol. 2001;281(6):2282-2288.

28. Finocchietto P, Barreyro F, Holod S, Peralta et al. Control of muscle mitochondria by insulin entails activation of Akt2-mtNOS pathway: Implications for the metabolic syndrome. PLoS One. 2008;3:e1749.

29. Costa LE, La Padula P, Lores Arnaiz S, et al. Long-term angiotensin II inhibition increases mitochondrial nitric oxide synthase and not antioxidant enzyme activities in rat heart. $J$ Hypertens. 2002;20(12):2487-2494.

30. Valdez LB, Zaobornyj T, Boveris A. Mitochondrial metabolic states and membrane potential modulate mtNOS activity. Biochim Biophys Acta. 2006;1757(3):166-172.

31. Valdez LB, Boveris A. Mitochondrial nitric oxide synthase, a voltage-dependent enzyme, is responsible for nitric oxide diffusion to cytosol. Front Biosci. 2007;12:1210-1219.

32. Alvarez S, Boveris A. Mitochondrial nitric oxide metabolism in rat muscle during endotoxemia. Free Radic Biol Med. 2004;37(9):1472-1478

33. Vanasco V, Magnani ND, Cimolai MC, et al. Endotoxemia impairs heart mitochondrial function by decreasing electron transfer, ATP synthesis and ATP content without affecting membrane potential. $J$ Bioenerg Biomembr. 2012;44(2):243-252.

34. Boveris A, Lores Arnaiz S, Bustamante J, et al. Pharmacologica regulation of mitochondrial nitric oxide synthase. Meth Enzymol. 2002;359:328-339.

35. Lores Arnaiz S, Coronel MF, Boveris A. Nitric oxide, superoxide, and hydrogen peroxide production in brain mitochondria after haloperidol treatment. Nitric oxide. 1999;3(3):235-243.

36. Lores Arnaiz S, Czerniczyniec A, Bustamante J, et al. Brain mitochondrial nitric oxide synthase: in vitro and in vivo inhibition 
by chlorpromazine. Arch Biochem Biophys. 2004;430(2):170-177.

37. Boveris A, D’ Amico G, Lores Arnaiz S, et al. Enalapril increases mitochondrial nitric oxide synthase activity in heart and liver. Antioxid Redox Signal. 2003;5(6):691-697.

38. Navarro A, Torrejon R, Bandez MJ, et al. Mitochondrial function and mitochondria-induced apoptosis in an overstimulated rat ovarian cycle. Am J Physiol Endocrinol Metab. 2005;289(6):1101-1109.

39. Bombicino SS, Iglesias DE, Rukavina Mikusic IA, et al. Hydrogen peroxide, nitric oxide and ATP are molecules involved in cardiac mitochondrial biogenesis in Diabetes. Free Radic Biol Med. 2017; 112:267-276.

40. Boveris A, Costa LE, Cadenas E, et al. Regulation of mitochondrial respiration by adenosine diphosphate, oxygen, and nitric oxide. Meth Enzymol. 1999;301:188-198.

41. Cleeter MW, Cooper JM, Darley Usmar VM, et al. Reversible inhibition of cytochrome $c$ oxidase, the terminal enzyme of the mitochondrial respiratory chain, by nitric oxide. Implications for neurodegenerative diseases. FEBS Lett. 1994;345(1):50-54.

42. Brown GC, Cooper CE. Nanomolar concentrations of nitric oxide reversibly inhibit synaptosomal respiration by competing with oxygen at cytochrome oxidase. FEBS Lett. 1994;356(2-3):295-298.

43. Takehara Y, Nakahara H, Inai Y, et al. Oxygen-dependent reversible inhibition of mitochondrial respiration by nitric oxide. Cell Struct and Funct. 1996;21(4):251-258.

44. Poderoso JJ, Carreras MC, Lisdero C, et al. Nitric oxide inhibits electron transfer and increases superoxide radical production in rat heart mitochondria and submitochondrial particles. Arch Biochem Biophys. 1996;328(1):85-92.

45. Iglesias DE, Bombicino SS, Valdez LB, et al. Nitric oxide interacts with mitochondrial complex III producing antimycin-like effects. Free Radic Biol Med. 2015;89:602-613.

46. Pacher P, Beckman JS, Liaudet L. Nitric oxide and peroxynitrite in health and disease. Physiol Rev. 2007;87(1):315-424.

47. Bartesaghi S, Radi R. Fundamentals on the biochemistry of peroxynitrite and protein tyrosine nitration. Redox Biol. 2018;14:618-625.

48. Ferrer Sueta G, Campolo N, Trujillo M, et al. Biochemistry of peroxynitrite and protein tyrosine nitration. Chem Rev. 2018;118(3):1338-1408.

49. Koppenol WH. The basic chemistry of nitrogen monoxide and peroxynitrite. Free Radic Biol Med. 1998;25(4-5):385-391.

50. Radi R, Peluffo G, Alvarez $\mathrm{MN}$, et al. Unraveling peroxynitrite formation in biological systems. Free Radic Biol Med. 2001;30(5):463-488.

51. Radi R, Beckman JS, Bush KM, et al. Peroxynitrite oxidation of sulfhydryls: the cytotoxic potential of superoxide and nitric oxide. $J$ Biol Chem. 1991;266(7):4244-4250.

52. Pryor WA, Jin X, Squadrito GL. One- and two-electron oxidations of methionine by peroxynitrite. Proc Natl Acad Sci. U S A. 1994; 91(23):11173-11177.

53. Bartlett K, Church DF, Bounds PL, et al. The kinetics of the oxidation of Lascorbic acid by peroxynitrite. Free Radic Biology and Medicine. 1995;18(1):85-92.

54. King PA, Anderson VE, Edwards JO, et al. A stable solid that generates hydroxyl radical upon dissolution in aqueous solution: reactions with proteins and nucleic acid. J Am Chem Soc. 1992;114(13):5430-5432.
55. Radi R, Beckman JS, Bush KM, et al. Peroxynitrite-induced membrane lipid peroxidation: the cytotoxic potential of superoxide and nitric oxide. Arch Biochem Biophys. 1994;288(2):481-487.

56. Darley Usmar VM, Hogg N, O Leary VJ, et al. The simultaneous generation of superoxide and nitric oxide can initiate lipid peroxidation in human low density lipoprotein. Free Radic Res Commun. 1992;17(1):9-20.

57. Radi R. Protein tyrosine nitration: biochemical mechanisms and structural basis of functional effects. Acc Chem Res. 2013;46(2):550-559

58. Souza JM, Peluffo G, Radi R. Protein tyrosine nitration-functional alteration or just a biomarker? Free Radic Biol Med. 2008;45(4):357366.

59. Valdez LB, Alvarez S, Arnaiz SL, et al. Reactions of peroxynitrite in the mitochondrial matrix. Free Radic Biol Med. 2000;29(34):349-356.

60. Valdez LB, Bandez MJ, Navarro A, Boveris A. Brain mitochondrial dysfunction and complex I syndrome in Parkinson's disease. In: Ed. Ranna AQ, editor. Etiology and Pathophysiology of Parkinson's disease. Croatia: InTech; p. 317-328.

61. Valdez LB, Zaobornyj T, Bombicino S, et al. Complex I syndrome in myocardial stunning and the effect of adenosine. Free Radic Biol Med. 2011;51(6):1203-1212.

62. Bombicino SS, Iglesias DE, Rukavina Mikusic IA, et al. Diabetes impairs heart mitochondrial function without changes in resting cardiac performance. Int J Biochem Cell Biol. 2016;81(Pt B):335345 .

63. Navarro A, Boveris A. Rat brain and liver mitochondria develop oxidative stress and lose enzymatic activities on aging. Am J Physio Regul Integr Comp Physiol. 2004;287(5):1244-1249.

64. Boveris A, Carreras MC, Poderoso JJ. The regulation of cell energetics and mitochondrial signaling by nitric oxide. In: Ignarro L. editor. Nitric Oxide: Biology and Pathobiology. 2nd ed. London: Elsevier Academic Press; 2010:441-482.

65. Valdez L, Bombicino S, Iglesias D, et al. Mitochondrial complex I inactivation after ischemia-reperfusion in the stunned heart. In: Gelpi R, Boveris A, Poderoso JJ, editors. Biochemistry of Oxidative Stress: Physiopathology and Clinical Aspects. Advances in Biochemistry in Health and Disease. USA: Springer; 2016:245-257.

66. Costa LE, Boveris A, Koch OR, et al. Liver and Heart mitochondria in rats submitted to chronic hypobaric hypoxia. Am J Physiol. 1988;255(Pt 1):123-129.

67. Poderoso JJ, Carreras MC, Schöpfer F, et al. The reaction of nitric oxide with ubiquinol: kinetic properties and biological significance. Free Radic Biol Med. 1999;26(7-8):925-935.

68. Antunes F, Boveris A, Cadenas E. On the mechanism and biology of cytochrome oxidase inhibition by nitric oxide. Proc Natl Acad Sci U $S$ A. 2004;101(48):16774-16779.

69. Boveris A, Stoppani AO. Inhibition of electron and energy transfer in mitochondria by 19-nor-ethynyltestosterone acetate. Arch Biochem Biophys. 1970;141(2):641-655.

70. Litterio MC, Vazquez Prieto MA, Adamo AM, et al. (-)-Epicatechin reduces blood pressure increase in high-fructose-fed rats: effects on the determinants of nitric oxide bioavailability. $J$ Nutr Biochem. 2015;26(7):745-751. 